Wembley, a spirited defence is made of mass production. The chief complaint about this method is that the products lack individuality, and hence the inference is sometimes erroneously drawn that they are 'inferior'. From the economic and from nearly every other point of view, mass production is the best. Unfortunately, there seems little prospect of voltage standardisation-even in Great Britain seven voltages lying between 200 and 260 are in use-and there seems no hope of world agreement. Although great efforts have been made to standardise the diffusing 'pearl' finish for the bulbs, many users cling obstinately to the time-honoured glare of the unshaded bulb. The factory produces no less than 84 different types of product. This large number is made necessary by the lack of standardisation in the country.

\title{
Biological Oxidation.
}

$\mathrm{O}^{\mathrm{N}}$ Mar. 6, Prof. H. Wieland gave the second Pedler Lecture before the Chemical Society, his subject being "Recent Researches on Biological Oxidation". Attempts have been made, he said, to formulate the vital process of combustion according to a single scheme. A ' respiratory ferment' catalysing the process is considered by Warburg to be related to hæmin, and Liebig put forward the hypothesis that iron accelerates vital oxidations. If we adopt this view, we are faced with the difficulty of understanding why the activated oxygen does not indiscriminately oxidise every substance which the cell presents to it. Yet if the process of biological hydrolysis is not carried out by any single ferment system, each kind of substrate being split by its own specific enzyme, it is unlikely that a single catalyst will suffice for the much more complicated process of the oxidative destruction of organic molecules.

No fundamental difference is encountered in the nature of enzymes throughout the vast range of living organisms, ascending from unicellular fungi to man; yet we lack the means with which to accomplish the complete degradation, by dead material, of a substrate familiar to the cell. Hence it would appear that the available enzymatic activity of respiration is closely connected with that regulating principle which, for want of more exact knowledge, we can but describe by a circumlocution called life. Since the higher we go up the phylogenetic scale the more delicate and complex becomes the nature of biological oxidation, a preliminary study should be concerned with the aerobic fungi.

Prof. Wieland discussed the mechanism of the acetic acid fermentation, characterising the transformation as a dehydrogenation process, since quinone or methylene blue may replace the oxygen. The aerobic process is inhibited by quinone as well as by hydrocyanic acid, the difference being that only the former participates in the enzymic reaction. The intermediate formation of hydrogen peroxide as a primary product of biological oxidation is not easy of demonstration, on account of the presence of catalases which cannot, as a rule, be separated from the dehydrases and are also sensitive to hydrocyanic acid. The study of milk, however, affords such an opportunity. Prof. Wieland said that the observation of reducing action in the cell does not necessitate postulation of the existence of special reducing ferments, for reduction products would be formed by the intervention of various hydrogen acceptors in the process of dehydrogenation. The enzyme reactions of milk have also contributed to an understanding of catalase action, which appears to be biologically related to the utilisation of oxygen by the cell. The two dehydrogenating ferments of milk are clearly of general biological importance, since they have been found also in the liver and other organs.

A third enzyme system, found in muscle, is concerned chiefly with the dehydrogenation of succinic to fumaric acid, and both oxygen and methylene blue act as acceptors of the hydrogen. This reaction can be followed further biologically to the pyruvic acid stage, and probably even beyond this. Pyruvic acid, as a product of the dehydrogenation of lactic acid, is on the main line of biological degradation. If we accept enzymic reactions involving hydrogen peroxide, with hydrolysis and condensation, as conditions governing cellular metabolism, we facilitate an understanding of the energy changes which constitute the life of the cell.

Discussing the correlative oxidation and reduction of aldehydes, Prof. Wieland referred to the aldehydrase, which was first described as a reducing enzyme in milk, was later also recognised as an oxidase, and is moreover able to dismute aldehydes into acid and alcohol. Although the theory that a heavy metal-more particularly iron--takes part in biological oxidations has acquired a certain measure of probability, the recognition of iron as a constituent of oxidising enzymes in no way implies that it functions as an oxygen activator. Ferrous iron rather associates itself with the substrate of the oxidation, forming a complex in which the hydrogen atoms to be removed in the dehydrogenation process become labile. A clear understanding of the complex course of biological oxidation has, however, not yet been obtained. We must advance step by step by the study of such chemically intelligible partial reactions as can be followed accurately.

\section{Plantation Rubber Research.}

THE Annual Report of the Rubber Research Institute of Malaya for 1929 covers the third completed year of active operation, as although the Institute came into existence on Sept. 1, 1925, its activities can only be said to date from the appointment of a director in September 1926. The revenue of the Institute is nominally provided by the Governments of the Straits Settlements, Federated Malay States, Johore, Kedah, Kelantan, and Trengganau from a cess on exported rubber, but with the exception of the last, the cess has not been levied, equivalent payments out of revenue having been made. Since July 27, 1929, Major B. J. Eaton has acted as director, an appointment which has recently been confirmed: and changes in personnel and shortage of staff hindered the work of the Institute in several directions during the year, notably in the advisory work on behalf of estates. A considerable proportion of this advisory work on problems such as manuring, budding, and seed selection, replanting and rejuvenation of rubber areas, is essentially applied research, and useful and valuable results are anticipated. Such practical work may indeed require to precede the slower process of scientific development, and the film propaganda among small-holders, for which a motor van and apparatus have been approved, should materially help in the development of better conditions on small-holdings.

An important division of the Institute is concerned

No. 3202, VoL. 127] 
with soil investigations. Our knowledge of and methods of soil investigation are, however, not sufficiently advanced, particularly in connexion with permanent crops such as rubber, to enable recommendations to be made in many cases from the results of a soil analysis alone. Short and rapid methods of analysis are being investigated, and valuable information is being obtained as to probable soil deficiencies, particularly in nitrogen and potash, from field observations. The problem is specially important in relation to the manuring or rejuvenation of very poor areas of rubber. Other work in the same division is concerned with soil conservation and bacteriology, and studies of the relation of soil fungi and bacteria to the soil humus and of the value of leguminous and green cover crops to soil bacteria have been commenced.

The botanical division has reported considerable progress in such practical problems as budding, and investigations on the artificial pollination of flowers (from various classes on Pilmoor estate) and on seed selection have continued. No new diseases of importance are reported, but the pathological division directs attention to the urgent need for a thorough investigation of the relative value of well-known fungicidal chemicals compared with proprietary fungicides. Many of the latter are equally effective, and their use is determined chiefly by relative cost. A determination not only of the fungicidal properties but also of their penetrative effect on the parts of the plant treated is required. Differences in penetrative power affect the toxicity, and this is specially important in regard to bark renewal on the tapping panel. The problem of 'mouldy rot' caused by the fungus Sphceronema fimbriatum is one of special interest in regard to fungicidal treatment, which is also important in the case of secondary leaf fall due to the mildew fungus Oidium Hevece, owing to the danger of the fungus becoming more adapted to the host.

Investigations at the Institute have thrown new light on the origin and incidence of "brown bast'. Chemical and bacteriological investigations of the production of white sole crepe--the demand for which is regarded as retrograde-the preservation of latex, effects of moulds on rubber, and on various factory problems are reported; while considerable progress has been made on the experimental station, 905 acres out of the approximately 2000 acres having now been opened: $571 \frac{1}{2}$ acres of this have been planted and preliminary records of value should be available during 1930. The value of treating young rubber with cattle manure on a particular type of soil has already been demonstrated.

\section{University and Educational Intelligence.}

Cambridge.-The Appointments Committee of the Faculty of Physics and Chemistry has appointed Mr. P. M. S. Blackett, King's College, to be University lecturer in physics; Dr. P. J. Durrant, of Selwyn College, and Dr. F. P. Bowden, of Gonville and Caius College, to be University demonstrators in chemistry.

The General Board has recommended that a readership and a University demonstratorship in geophysics be established in the Faculty of Mathematics, and that Dr. H. Jeffreys, of St. John's College, be appointed reader.

Dr. J. Wishart has been appointed University lecturer in statisties in succession to Mr. G. Udny Yule, who has been appointed reader in statistics.

The Sedgwick Prize for 1931, for an essay on geology, has been awarded to Dr. C. E. Tilley, of Emmanuel College.
LoNDON.- The following doctorates have been awarded: D.Sc. in Chemistry to Mr. A. M. Ward, Birkbeck College, for a thesis entitled "Investigations on the Bivalency of Carbon", consisting of four published papers (Jour. Chem. Soc., 1927, 1929, 1930); D.Sc. in Physics to Mr. S. H. Piper, King's College, for a thesis entitled " $\mathrm{X}$-ray Studies of Long-chain Compounds", comprising three published papers (Jour. Chem. Soc., 1929 ; Trans. Far. Soc., 1929; and Proc. Roy. Soc., A, 1930); D.Sc. in Entomology to Mr. W. J. Hall, Imperial CollegeRoyal College of Science, for a thesis entitled "The South African Citrus Thrips in Southern Rhodesia" and "Observations on the Coccidæe of Southern Rho. desia ", parts 1-3, and eight subsidiary contributions D.Sc. in Geology to Dr. A. Brammall for a thesis entitled "Gold and Silver in the Dartmoor Granite" (Min. Mag., vol. 21, 1926), "The Dartmoor Granite" (Proc. Geol. Assoc., vol. 27, 1926), "Dartmoor Detritals -A Study in Provenance" (Proc. Geol. Assoc., vol. 39, 1928), "Notes on Fissure-Phenomena and LodeTrend on Dartmoor" (Trans. Roy. Geol. Soc. of Cornwall, vol. 16, 1928), and eight subsidiary contributions.

During the seventh year of the Ella Sachs Plotz Foundation for the advancement of scientific investigation, seventy-eight applications for grants were received by the trustees, sixty-two of which.came from twelve different countries in Europe and Asia, the remaining sixteen coming from the United States. The total number of grants made during this year was twenty-five, one of these being a continued annual grant. Twenty-one of the new grants were made to scientific workers in countries outside the United States. In the seven years of its existence, the Foundation has made one hundred and twenty grants and investigators have been aided in the United States, Great Britain, France, Germany, Austria, Hungary, Switzerland, Italy, Sweden, Esthonia, Czechoslovakia, Poland, Chile, Syria, and Belgium. Applications for grants to be held during the year 1931-32, to be sent to Dr. Joseph C. Aub, Collis P. Huntington Memorial Hospital, 695 Huntington Avenue, Boston, Massachusetts, should be in the hands of the Executive Committee before May 1, 1931.

The Carnegie Trust for the Universities of Scotland has allocated, as grants for the quinquennium ending September 1935 for universities and extra-mural institutions respectively, $£ 224,700$ and $£ 34,325$. Since the Trust's operations began, in 1902, the total grants have been distributed as follows: for libraries, $£ 159,850$; buildings and permanent equipment, $£ 905,101$; endowment of chairs, lectureships, and pension schemes, etc., $£ 437,701$; other purposes, $£ 143,730$. A noticeable feature of the last quinquennial allocation is the assistance towards such student purposes as residential halls, students' unions, and playing fields, which have always specially appealed to the Trust. Assistance to students in payment of class fees for 1929-30, accounting for nearly half of the 'Trust's expenditure, amounted to $£ 56,316$, distributed among 4531 beneficiaries. Voluntary repayments by 54 former beneficiaries $(21$ men and 33 women) amounted during the same year to $£ 2036$. Apart from the quinquennial grants scheme and assistance to students, the Trust spent last year on fellowships, scholarships, and other grants for the endowment of research, $£ 19,516$. Under its research scheme the Trust recently instituted senior scholarships, of the annual value of $£ 200$, to provide, in particular, for the Ph.D. candidate, who must generally be engaged for three years at post-graduate work before he presents his thesis for that degree.

No. 3202, VoL. 127] 